\title{
Letter to a Young Scientist
}

\section{From State Science Day to Commanding a Nuclear Submarine}

\section{By CAPT David Roberts, USN (Ret.)}

CAPT David Roberts, USN (Ret.), attended Westerville North High School, Westerville, Ohio, and enjoyed (among other extracurricular activities) competing in science fairs, culminating at the State Science Day. Following graduation, he earned degrees in navalarchitecture from the US Naval Academy and engineering management from George Washington University. He proudly served in the US Navy for thirty years, commanding the submarine USS Dallas, the Naval Submarine School, and the Submarine Learning Center. Following retirement from the Navy, he started a second career in business, where he hopes to continue to make a difference in the world.

I DIDN'T ALWAYS WANT TO BE THE CAPTAIN OF a nuclear-powered submarine. Honestly, I didn't know what I wanted to be when I grew up. But looking back now, I can clearly see how a young scientist ended up destined to command the submarine from the movie The Hunt for Red October.

\section{Follow Your Passion}

I have always loved math and science but never considered myself to be a pure scientist. My passion lies in applying math and science, specifically designing and building mechanical

\section{I didn't always want to be the captain of a nuclear-powered submarine.} contraptions. For as long as I can remember, I have always loved drawing the things I wanted to buildthen collecting the materials and building them. In grade school I built small, personalized gifts made of wood for family members. In middle school, I rolled sheet metal to make candle holders and lamps. In high school, after attending a summer program at the US Naval Academy where I learned about ship design, I built a 33-foot long by 3-foot wide by 2 -foot deep towing tank.

"A towing tank? Really?" At first, my parents thought (like I did) that this would be too big of a project to pursue. Their eventual encouragement, however, gave me the confidence I needed to build the tank, so I went for it! The purpose of the tank was to test model ships for their efficiency in moving through the water. The mechanical design and construction were fun and easy since this was what I loved to do. Designing a circuit board (with lights and switches that would measure collected data) and writing a computer program (to make sense of the data) was much more challenging. But with the help of fantastic mentors and teachers, and plenty of trial and error, the electronics and software worked; I was able to replicate resistance data similar to that at the US Naval Academy. It was the biggest and most complex project of my life, and I'm convinced that it was possible because I followed my passion to design and build.

-What is yourpassion and how are you pursuing it?

\section{Ask Questions}

As an introvert, I'm happy to keep quiet, listen, and take notes in class; let the other students ask questions. This approach to learning worked well for me until I got to high school. When classes got harder, I found myself falling behind because I wasn't an active participant. Once I started asking questions, I became invested in my education and started learning faster. Everyone learns differently: some by reading and studying on their own, some in groups, some can simply listen to a lecture and absorb the material, others need to experience the subject matter to fully grasp its meaning and purpose. No matter your method of teaching yourself, all types of learning start with curiosity.

My high school physics teacher, Mr. Dave Weaner, a lifelong teacher in Westerville, Ohio, taught me the value of being curious. Being mechanically minded, I had more interest in learning about statics and dynamics than particle physics, but Mr. Weaner encouraged me to be curious. After the first few classes learning about protons, neutrons, and electrons, I started asking questions (mostly

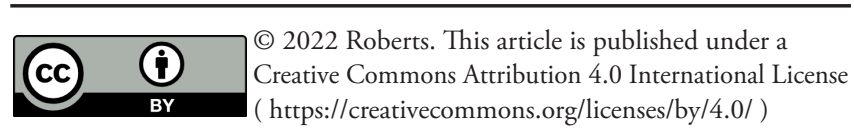


why? questions) and found my understanding skyrocketing. This boosted my self-confidence, and oddly, I started enjoying particle physics. When we reached learning about When classes got harder, I found myself the fission process, I was hooked! Producing enormous amounts of power from tiny particles was fascinating, and made me even more curious-how could the power produced by fission be applied in the world? This simple advice, to ask questions, led to expanding my curiosity; it set the stage for a career in the Navy's nuclear propulsion program. Who knew that a physics class at Westerville North High School would lead to commanding USS Dallas?

-Are you curious?

\section{Be Teachable}

Early in my Navy career, I was fortunate to be given the opportunity to lead a team of sailors as the Chief Engineer aboard the nuclear-powered submarine USS Miami. About $40 \%$ of a submarine crew consists of nuclear-trained sailors who operate and maintain the electronic, electrical, and mechanical systems of the reactor, as well as ensuring that strict chemistry and radiological control requirements are met. Our team on Miami was fantastic, providing safe and reliable propulsion and electrical power so the ship could perform its mission. We also scored very well on our annual inspections, and the Captain was wellpleased with our performance.

When a new Captain arrived onboard, he was less enamored with John Paul Jones, father our department. Although we once of the modern Navy, had done well in the past, he noticed that our performance was slipping in many areas. Equipment repairs were not being aggressively pursued, our procedural error rate was creeping up, and our training program needed an overhaul. All signs led to a declining department, but I couldn't see it. Not only was I unable see it but I also refused to listen to the new Captain's opinions (not a great career move!). I was too proud of our past performance to learn about how we could improve, now and in the future.

Good scientists objectively study evidence to determine hypotheses, conduct experimental trials, and eventually declare conclusions. They work hard to prevent preconceived notions and emotional biases, which can cloud their judgment, so truth can be revealed. Scientists let the science teach them! The new Captain provided me evidence of a declining department, but I let my opinions override the evidence. Embarrassingly, I was not behaving like a scientist and, in fact, made myself unteachable. Thankfully, the new Captain mentored me, patiently allowed me to conclude for myself that we had a problem, and guided me through the changes needed to return to a high-performing department. This was a hard lesson to learn, but it paid dividends later in my career when I could share this story and build teachable leaders and teams.

\section{-Are you teachable?}

\section{Take Risks}

John Paul Jones, father of the modern Navy, once said, "Those who will not risk cannot win." Although he spoke these words centuries ago, they are just as applicable today.

My passion for designing and building led me to major in naval architecture in college. Because I loved designing, building, and testing ships, I expected to serve on them in the Navy when I graduated; this instead of flying planes or diving on submarines. Having been to sea on warships during my summers at the Naval Academy, I knew what was ahead for my five years of required service following of the modern Navy, graduation-and I ill not risk cannot win." arefew experiences more exciting in life than being on the high seas, especially at sunset or sunrise!

As graduation approached, I decided to request duty on a nuclear-powered surface ship, which was considered a challenging assignment given the additional training required at Admiral Rickover's Nuclear Power School. It seemed to be right up my alley-the fun of driving surface ships combined with nuclear science and engineering, all in one place! To confirm my decision, I asked a few officers for their opinions. Surprisingly and overwhelmingly they recommended that I join the Silent Service: submarines. They affirmed my excitement for 
nuclear science and engineering but also regaled me with stories of nuclear science and engineering while underwater! Although exciting, it wasn't a risk I was initially willing to take: What if the submarine can't get back to the surface after diving? What if I'm claustrophobic? What if I hate submarine duty? My naval career would be over.

Knowing that the Navy would have the final say (isn't that why they call them military orders?), I decided to ask further questions. After hearing more about the exciting operations that submarines perform, and the close-knit crews that operate submarines, I decided to make the jump and join the Submarine Force. In hindsight, it was the best professional advice I ever received. I'll be forever grateful for the officers who invested time in me; they each helped me to realize that Submarine Service was the right choice.

- How do you approach risk-taking? Are you risk adverse? What risks should you take?

\section{It's All About People}

In conclusion, no one gets to where they're going on their own. Accomplishing goals and making dreams come true requires the help of others: Others who know what's required saw something in me, and they belped to take the road you me find my way-it's all about people. are on. Others who are of charge. And others who want to do for you what people once did for them.

I've been lucky to have people throughout my life who were not only willing to help me but who also believed in me. They taught me to follow my passions, to ask questions, to be teachable, to take risks, and so many other things. They saw something in me, and they helped me find my way-it's all about people.

-Do you have people in your life who are helping you achieve your goals? 